\title{
EPSL
}

Earth and Planetary Science Letters 146 (1997) 59-72

\section{Deep sea and lake records of the Southeast Asian paleomonsoons for the last 25 thousand years}

\author{
Chi-Yue Huang ${ }^{\text {a. }}$, Ping-Mei Liew ${ }^{a}$, Meixun Zhao ${ }^{b}$, Tzu-Chun Chang ${ }^{a}$, \\ Chao-Ming Kuo a , Min-Te Chen ${ }^{c}$, Chung-Ho Wang ${ }^{d}$, Lian-Fu Zheng ${ }^{\text {e }}$ \\ a Department of Geology, National Taiwan University, 245, Choushan Road, Taipei, 107 Taiwan, ROC \\ ${ }^{b}$ Department of Earth Sciences, Dartmouth College, Hanover, NH 03755, USA \\ ' Institute of Applied Geophysics, National Taiwan Ocean University, Keelung, Taiwan, ROC \\ 'Institute of Earth Sciences, Academia Sinica, Nankang, Taipei, Taiwan, ROC \\ 'Second Institute of Oceanography, State Oceanic Administration, Hangzhou 310012. People's Republic of China
}

Received 4 March 1996; revised 10 October 1996; accepted 12 October 1996

\begin{abstract}
High resolution paleoceanographic proxy records from a deep-sea core in the northern South China Sea (SCS) and palynological records from a lake core in central Taiwan have been measured for the last $25 \mathrm{kyr}$. The variations in these proxy records are interpreted in terms of the past variation in the Asian monsoons. The two consistent and complementary records suggest that the East Asian monsoon system has fluctuated significantly from a strengthened winter monsoon during the last glaciation (25,000-12,000 yr BP) through a moderate to weak winter and summer monsoons during the deglaciation $(12,000-10,000 \mathrm{yr} \mathrm{BP})$ to an enhanced summer monsoon in the Holocene. Strengthening of the winter monsoon during the glacial is deduced from decreases in winter SST and increases in productivity indicators, such the abundances of alkenones and total organic carbon in the SCS. A stronger summer monsoon during the Holocene is inferred from the increases in floral productivity, the sedimentation rate of peat, the deposition of storm-related clay layers in the lake sediment, and the higher abundance of thermophyte Castanopsis. The $25 \mathrm{kyr}$ paleomonsoon history registered in the SCS core and the Taiwan lake sediments is in agreement with the climatic records of the Chinese Loess plateau.
\end{abstract}

\section{Introduction}

Generally speaking, monsoon systems are driven by the differential heating between the continent and the adjacent oceans $[1,2]$. Due to their importance in modulating regional weather and climate, many investigations have been carried out to document the

\footnotetext{
Corresponding author. Tel: +8862363 3514. Fax: +8862 3636095 . E-mail: huangcy@ccms.ntu.edu.tw
}

variations in the monsoon climate during glacial/interglacial cycles [1-4]. The East Asia Monsoon is characterized by the seasonal changes in air pressures, wind systems, rainfall and temperature gradient over East and Southeast Asia [5]. Unlike the Southwest Asian monsoon which is characterized by a strong summer monsoon $[1,3,6,7]$, the East Asia Monsoon is characterized by both summer and winter monsoons [2,5]. Their influence on the regional climates extends from Northern China to the South 
(a)

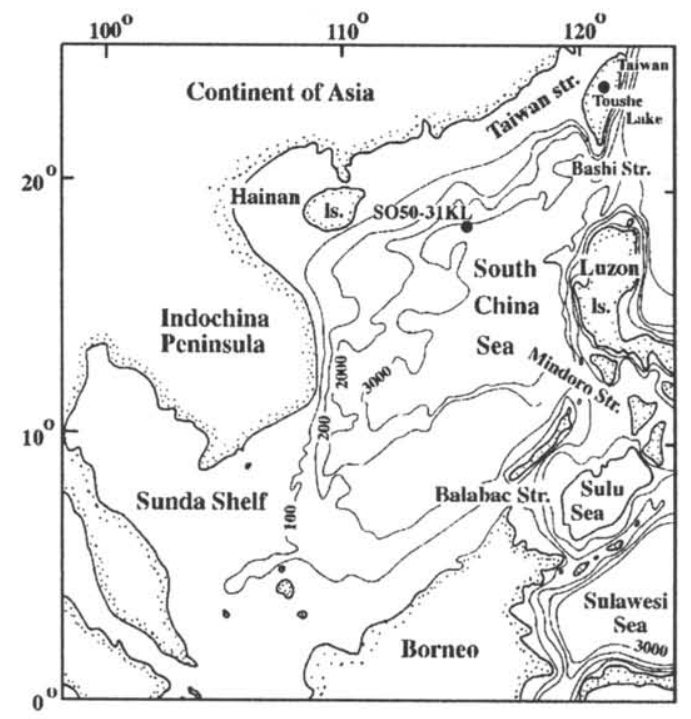

(b)

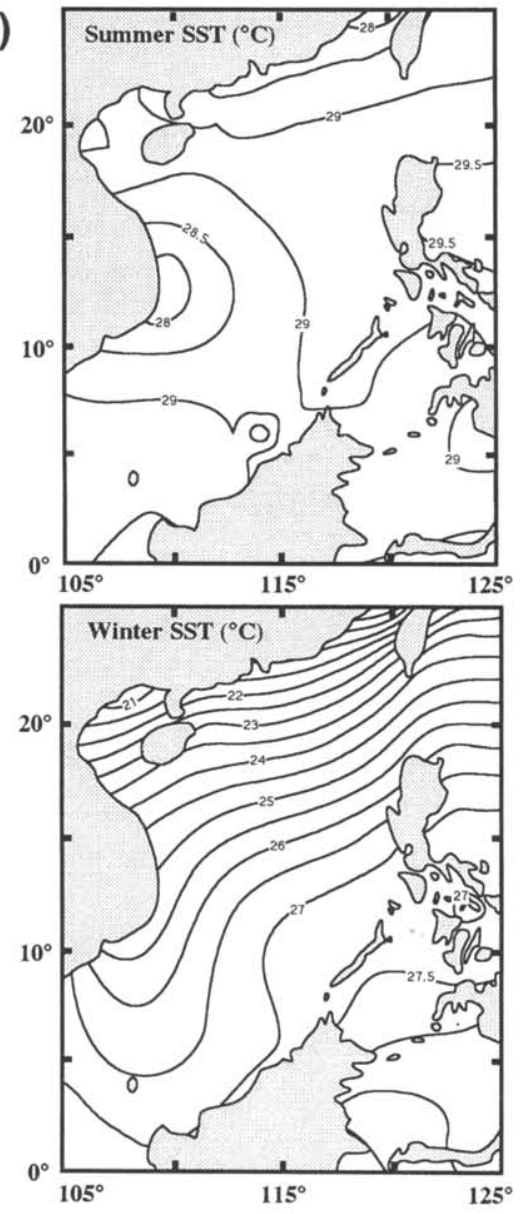

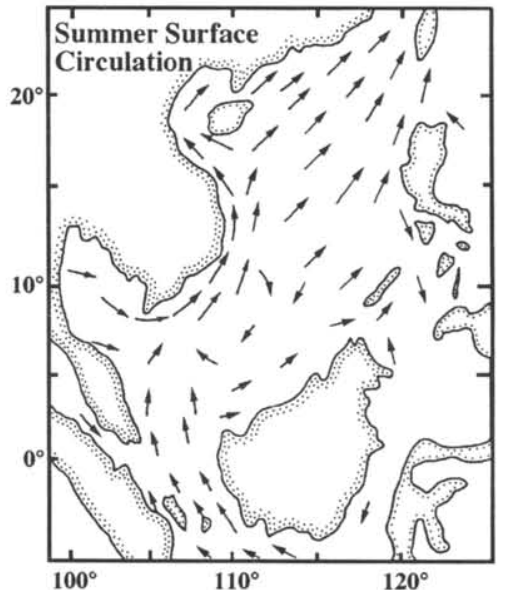

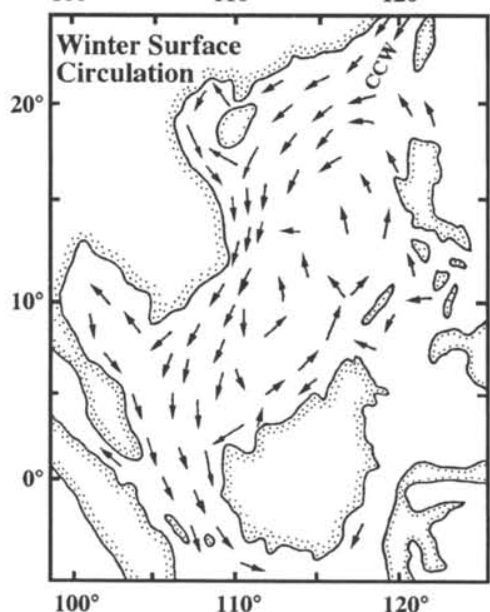


Table 1

Distribution of vegetation zones in central Taiwan [17]

\begin{tabular}{|c|c|c|c|}
\hline Vegetation zone & $\begin{array}{l}\text { Elevation } \\
\text { (m) }\end{array}$ & $\begin{array}{l}\text { Mean temperature } \\
\left({ }^{\circ} \mathrm{C}\right)\end{array}$ & Climatic zone \\
\hline Alpine vegetation & $>3600$ & $<5$ & Subarctic \\
\hline Albies Zone & $3100-3600$ & $5-8$ & Cold temperate \\
\hline Tsuga-Picea Zone & $2500-3100$ & $8-11$ & Cool temperate \\
\hline Quercus (Upper) Zone ${ }^{2}$ & $2000-2500$ & $8-14$ & Temperate \\
\hline Quercus (Lower) Zone $^{\text {a }}$ & $1500-2000$ & $14-17$ & Warm temperate \\
\hline Machilus-Castanopsis Zone & $500-1500$ & $17-23$ & Subtropical \\
\hline Ficus-Machilus Zone & $<500$ & $>23$ & Tropical \\
\hline
\end{tabular}

${ }^{a}$ On the leeward side, Quercus Zone is replaced by Alnus Zone at the same altitude. The Quercus Zone is characterized by the occurrence of Cyclobalanopsis and Quercus.

China Sea throughout the calendar year. Previous reconstructions of the East Asian paleomonsoon history have focused on the variability of the monsoons $[2,4,8,9]$ using proxies preserved in the loess-paleosol sequences in central China. These studies have generally concluded that the winter monsoon was strengthened during the last glacial period. In contrast, there has been little attention to the East Asian paleomonsoon signals recorded in the deep-sea cores off the Chinese coast, especially in the SCS [10]. Here we report high resolution paleoceanographic data from a deep-sea core in the northern SCS and palynological data from a lake core in central Taiwan to reconstruct the summer and winter Asian monsoon variations in the tropical regions for the last $25 \mathrm{kyr}$.

The South China Sea $\left(5-22^{\circ} \mathrm{N}, 110-120^{\circ} \mathrm{E}\right.$; Fig. la) is a semi-closed Asian marginal sea. High sedimentation rates along its northern slope $(8-20$ $\mathrm{cm} / \mathrm{kyr}$ ) provide good records for high resolution paleoceanographic and paleoclimatic reconstructions [11-14]. At present, the surface water circulation and sea surface temperature (SST) of the SCS are generally controlled by the monsoon climate [15]. During the winter, the dominant influence of the cold and dry northeasterly monsoon winds, together with the southward flow of the cold Chinese Coastal Waters (CCW) result in low SST in the northern SCS and a north $\rightarrow$ south gradient (Fig. 1b). During the summer, by contrast, the warm southwesterly monsoon winds and the warm Indian surface waters flow northeastward into the southern SCS through the Sunda Shelf. The resulting SST is relatively high and homogeneous all over the SCS $\left(28-29^{\circ} \mathrm{C}\right.$, Fig. 1b) [15-17]. During the last glaciation, the lowering of sea-level exposed the present-day shallow water gates between the SCS and the open ocean except for the Bashi Strait (sill depth: $2500 \mathrm{~m}$; Fig. 1a). Thus the SCS was more isolated and the surface circulation and biological productivity could have been quite different [10-14]. For example, the lowering of sea-level by approximately $120 \mathrm{~m}$ during the LGM could have inhibited the entry of cold CCW into the SCS through the Taiwan Strait ( $<70 \mathrm{~m}$ in depth) (Fig. 1a). Thus, the main mechanism of lowering the winter SST in the northern SCS during the last glaciation would be the cold winds resulting from the northeast winter monsoon.

Temperature and precipitation in central Taiwan are heavily influenced by the oscillations of the monsoon systems [18]. More than $70 \%$ of the annual rainfall (2000-2500 mm/yr) occurs during the warm season from June to August when the summer monsoon prevails (Fig. 2). In contrast, when the winter monsoon prevails, from October to April, the climate is cold and dry. Due to the steep slope and high elevation of the mountain range (up to $4000 \mathrm{~m}$ ), a varicty of floral assemblages can be found in Tai-

Fig. 1. Physiographic map of the South China Sea showing (a) locations of deep-sea core SO50-31KL and Toushe Lake core in central Taiwan, directions of the Chinese Coastal Waters (CCW) into the northern SCS during the winter season, (b) summer and winter sea surface temperature, and the summer and winter surface water circulations $[49,16]$. 


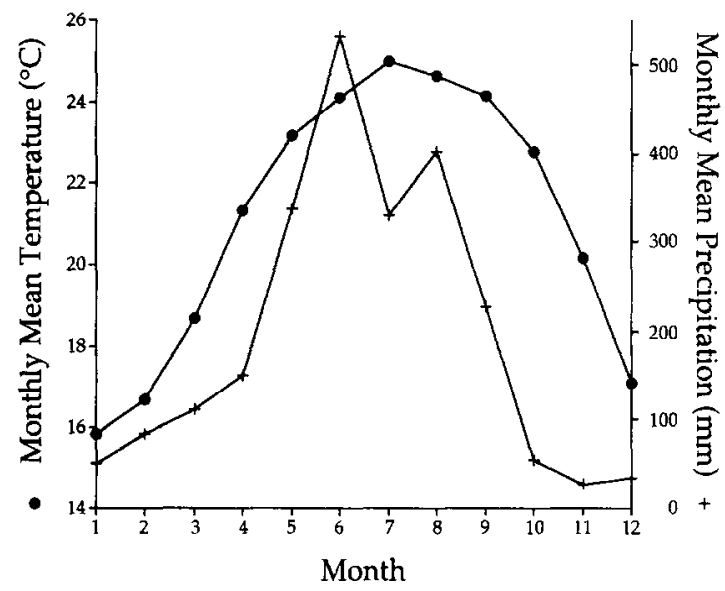

Fig. 2. The 30 year average mean monthly temperature $(O)$ and precipitation $(t)$ for the Toushe region $\left(23^{\circ} 52^{\prime} \mathrm{N}, 120^{\circ} 54^{\prime} \mathrm{E}\right.$, elevation $650 \mathrm{~m}$ ) in central Taiwan.

wan, ranging from the tropical to the subarctic. Seven vegetation zones have been recognized and are listed in Table 1 [19]. During the latest Pleistocene these floral zones migrated up and down in accordance with the global glacial-interglacial climatic fluctuations [20-22]. The present-day vegetation in the Toushe area $(650 \mathrm{~m}$ in elevation) in central Taiwan belongs to the Machilus-Castanopsis Zone (elevation $1500-500 \mathrm{~m}$; temperature range 17 $23^{\circ} \mathrm{C}$; Table 1). The Toushe Basin is a desiccated dry lake $(1 \times 1.88 \mathrm{~km})$ formed by strike-slip faulting in the late Quaternary [23]. The lake is filled with more than $40 \mathrm{~m}$ of peat, in the central part of which the upper $14.7 \mathrm{~m}$ sequence represents the last $25.2 \mathrm{kyr}$.

\section{Core sites and study methods}

\subsection{Deep-sea core}

Core SO50-31KL was drilled in the northern SCS in $1987\left(18^{\circ} 45.3^{\prime} \mathrm{N}, 115^{\circ} 52.39^{\prime} \mathrm{E}\right.$, water depth 3360 $\mathrm{m})$. The age model of this core has been established by accelerator mass spectrometry (AMS) ${ }^{14} \mathrm{C}$ dating of mixed planktonic foraminifera and the foraminifera oxygen isotope stratigraphy. No visible turbidite layers were found in the core which is also supported by the normal sequence of the AMS ${ }^{14} \mathrm{C}$ dates. The sedimentation rate is $15 \mathrm{~cm} / \mathrm{kyr}$ for the glacial and 7 $\mathrm{cm} / \mathrm{kyr}$ for the Holocene (Fig. 3). The increase in glacial sedimentation rate could be due to a low-stand of level [11] and, presumably, also an increase in eolian flux by an enhanced winter monsoon.

The sampling interval was $2 \mathrm{~cm}$, corresponding to $200-400 \mathrm{yr}$ in the Holocene and $100-150 \mathrm{yr}$ in the last glaciation. Oxygen isotopes of the planktonic foraminifera $G$. sacculifer $(>350 \mu \mathrm{m})$ were determined using a VG SIRA 10 isotope ratio mass spectrometer with a precision of $0.08 \% \circ( \pm 1 \sigma)$. Core $\mathrm{SO} 50-31 \mathrm{KL}$ is located near the present-day $\operatorname{CCD}(3500 \mathrm{~m})[24]$ and there is a high probability of carbonate dissolution in this core. Foraminifera-based SST estimation could not be easily applied to this core. Hence, we have used the $\mathrm{U}_{37}^{\mathrm{k}^{\prime}}$ method $[25,26]$ to estimate sea surface temperatures (SSTs) for the last 25 kyr. Long-chain unsaturated ketones (alkenones) were extracted from the sediments using organic solvent and determined by gas chromatography in the Organic Geochemistry Laboratory of the University of Bristol, UK [27]. The temperature was calculated using the calibration equation of Prahl et al. [28]:

$\operatorname{SST}\left({ }^{\circ} \mathrm{C}\right)=\left(\mathrm{U}_{37}^{\mathrm{k}^{\prime}}-0.039\right) / 0.034$

where $U_{37}^{k^{\prime}}=C_{37: 2} /\left(C_{37: 2}+C_{37: 3}\right)$.

Mass accumulation rates (MAR) of alkenones, total organic carbon and carbonate were calculated

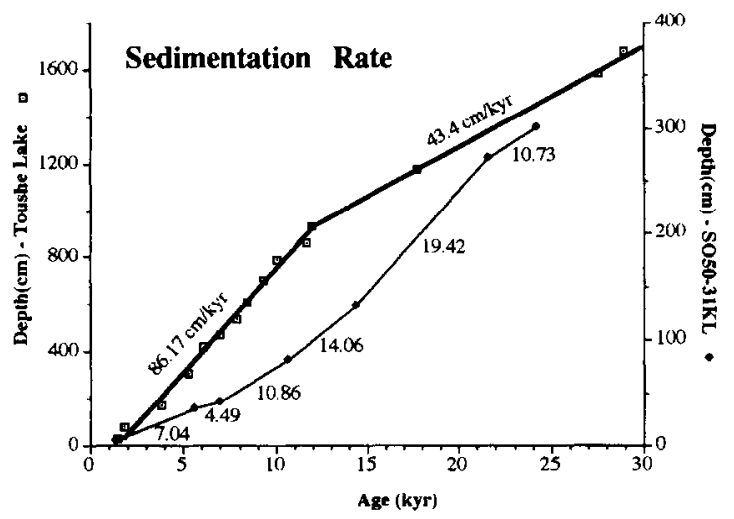

Fig. 3. Composite plot of depth vs. age for the deep-sea core SO50-31 KL and Toushe lake core. Ages were determined by ${ }^{14} \mathrm{C}$ dating of foraminifera and peat and corrected by $400 \mathrm{yr}$. For the deep-sea core the sedimentation rates were higher in the glacial, due to the wide exposure of continental shelf in the northem SCS, while the sedimentation rates of the lake core were lower during the last glacial, due to the low floral diversity and productivity under the cold and dry climate. 
using concentration and sedimentation rate data to estimate paleoproductivity [29].

\subsection{Toushe Lake sediment}

A $40 \mathrm{~m}$ long peat sequence from Toushe Lake $\left(23^{\circ} 49^{\prime} \mathrm{N}, 120^{\circ} 53^{\prime} \mathrm{E}\right.$, elevation $\left.650 \mathrm{~m}\right)$ in central Taiwan (Fig. 1a) was recovered in 1993. The age model of the lake core were determined by both conventional and AMS ${ }^{14} \mathrm{C}$ dating of the peat (Table 2; Fig. 3). The first $16.9 \mathrm{~m}$ of this lake core can be divided into two sections based on sedimentation rate. The first interval $(30-941 \mathrm{~cm}$, or $2000-12,500$ $\mathrm{yr} \mathrm{BP})$ has a constant and higher sedimentation rate of $87 \mathrm{~cm} / \mathrm{kyr}$. The second interval $(941-1690 \mathrm{~cm}$, or 12,500-29,000 yr BP) also has a constant, but lower sedimentation rate of $43 \mathrm{~cm} / \mathrm{kyr}$. At least 500 grains of the pollen in each sample were identified. In some herb-predominant samples, more than 100 grains of woody plant pollen were counted.

The interpretation of pollen taxa to paleoecological condition was based largely on studies of the ecology and altitude distributions of modem plants

\section{Table 2}

List of dated samples from Toushe lake sediments and marine core SO50-31KL

\begin{tabular}{|c|c|c|c|}
\hline \multicolumn{2}{|c|}{ Toushe Lake Core } & \multicolumn{2}{|c|}{ Deep-sea core SO50-31KL } \\
\hline $\begin{array}{l}\text { Depth } \\
(\mathrm{cm})\end{array}$ & $\begin{array}{l}\text { Age } \\
\text { (yr BP) }\end{array}$ & $\begin{array}{l}\text { Depth } \\
\text { (cm) }\end{array}$ & $\begin{array}{l}\text { Age } \\
\text { (yr BP) }\end{array}$ \\
\hline $30-40$ & $1840 \pm 50$ & $4-6$ & $1790 \pm 100$ \\
\hline $80-90$ & $2230 \pm 50$ & $34-36$ & $6063 \pm 89$ \\
\hline $172-182$ & $4230 \pm 50$ & $40-42$ & $7400 \pm 120$ \\
\hline $310-320$ & $5640 \pm 60$ & $80-82$ & $11,080 \pm 87$ \\
\hline $420-430$ & $6480 \pm 60$ & $132-134$ & $14,780 \pm 210$ \\
\hline $473-483$ & $7370 \pm 60$ & $272-274$ & $21,990 \pm 250$ \\
\hline $535-545$ & $8270 \pm 70$ & $300-302$ & $24,600 \pm 280$ \\
\hline $610-620$ & $8780 \pm 60$ & & \\
\hline $705-707$ & $9600 \pm 130^{a}$ & & \\
\hline $700-710$ & $9720 \pm 60$ & & \\
\hline $787-796$ & $10,450 \pm 70$ & & \\
\hline $861-870$ & $12,100 \pm 90$ & & \\
\hline $930-941$ & $12,350 \pm 90$ & & \\
\hline $1177-1187$ & $18,130 \pm 160$ & & \\
\hline $1587-1597$ & $28,000 \pm 250$ & & \\
\hline $1680-1690$ & $29,300 \pm 300$ & & \\
\hline
\end{tabular}

Dating was performed by the AMS ${ }^{14} \mathrm{C}$ method for the marine sediments and the conventional ${ }^{16} \mathrm{C}$ method for the lake sediments.

${ }^{4}$ This sample was also dated by the AMS ${ }^{14} \mathrm{C}$ method. in the mountain range of Taiwan [19]. The sampling interval for the palynological study is $10 \mathrm{~cm}$, which corresponds approximately to 240 year intervals in the last glaciation and 120 year intervals in the Holocenc. Pollen percentages of four tree taxa ( $\mathrm{Al}$ nus, Cyclobalnopsis, Quercus and Castanopsis) and three herbs (Artemisia, Cyperaceae and Gramineae) were determined to be ecologically significant and provide palynological insight in the lake core.

\section{Results and discussions}

\subsection{Paleomonsoon records in the SCS core}

The core SO50-31KL $\mathrm{U}_{37}^{\mathrm{k}^{\prime}}$ SST curve parallels the oxygen isotopic curve recorded by Globigerinoides sacculifer (Fig. 4). It shows a glacial/interglacial difference of $4^{\circ} \mathrm{C}$. The SST minimum is centered around the LGM, with a value of $22.5^{\circ} \mathrm{C}$ (Fig. 4). The SST increased sharply around $12,000 \mathrm{yr} \mathrm{BP}$ and reached $26.2^{\circ} \mathrm{C}$ around the Holocene Optimum at $6000 \mathrm{yr} \mathrm{BP}$ and to $26.5^{\circ} \mathrm{C}$ at $2000 \mathrm{yr} \mathrm{BP}$. It has been suggested that the $\mathrm{U}_{37}^{\mathrm{k}^{\prime}}$ index normally records the SST of the season of maximum coccolithophorids production [30-34]. However, core-top $\mathrm{U} 37 \mathrm{k}^{\prime}$ values often correlate well with average annual SST, suggesting no significant seasonal bias of alkenones in recording surface temperatures $[35,36]$. In the modern northern SCS, the marine productivity maximum occurs from early winter to early spring when the winter monsoon prevails [37]. However, the late Holocene $\mathrm{U}_{37}^{\mathrm{k}^{\prime}} \mathrm{SST}$ valuc of $26^{\circ} \mathrm{C}$ is almost the same as the present annual mean SST for this location, indicating the $\mathrm{U}_{37}^{\mathrm{k}^{\prime}}$ index also records the annual SST in the SCS. Several studies have indicated that the summer SST in the SCS has remained relatively constant over the last $30 \mathrm{kyr}[10,11,14]$. Thus, any significant change in the annual SST as recorded by the $U_{37}^{k^{\prime}}$ index is probably a result of the change in the winter SST. A simple exercise will indicate that the glacial/interglacial changes in winter SST is larger than the annual (the $\mathrm{U}_{37}^{\mathrm{k}^{\prime}}$ ) SST changes.

If we define Ts as the summer SST, Tw as the winter SST and Ta as the annual SST at a given time; $\mathrm{Ta}=(\mathrm{Ts}+\mathrm{Tw}) / 2=\mathrm{U}_{37}^{\mathrm{k}^{\prime}} \mathrm{SST}$. We also define $\delta \mathrm{Tx}$ as the difference in $\mathrm{Tx}$ for the late Holocene 
minus the $\mathrm{Tx}$ at a given time, where $\mathrm{x}$ could be $\mathrm{s}, \mathrm{w}$ or a. Hence $\delta \mathrm{Ta}=(\delta \mathrm{Ts}+\delta \mathrm{Tw}) / 2$. If we assume $\delta$ Ts is zero, then, $\delta \mathrm{Tw}=\delta 2 \mathrm{Ta}$. Thus, as a first-order approximation, the maximum glacial/interglacial Tw difference should be $8^{\circ} \mathrm{C}$, since $\delta \mathrm{Ta}$ is $4^{\circ} \mathrm{C}$ based on $\mathrm{U}_{37}^{\mathbf{k}^{\prime}}$ SST measurements. If $\delta \mathrm{Ts}$ is $2^{\circ} \mathrm{C}$, then $\delta \mathrm{Tw}$ would be $6^{\circ} \mathrm{C}$. This glacial/interglacial SST difference of $6-8^{\circ} \mathrm{C}$ is comparable with the recent transfer function estimates $[11,14]$. We admit that this calculation is too simplistic, however, it does illustrate two very important aspects of the glacial/interglacial changes in winter SST. Firstly, since summer SST has remained relatively constant over the last 25 kyr, changes in the $\mathrm{U}_{37}^{\mathrm{k}^{\prime}}$ SST mainly reflected changes in the winter SST. Hence the winter SST profile should be very similar to the $\mathrm{U}_{37}^{\mathrm{k}^{\prime}}$ SST profile. Sec- ondly, the glacial/interglacial difference in winter SST is larger than the $\mathrm{U}_{37}^{\mathrm{k}^{\prime}}$ SST difference. Using these assumptions, we will take the $U_{37}^{k^{\prime}}$ SST profile as a proxy for the winter SST trend only, not the absolute value. As we have argued in the introduction section, the lowering of sea-level by approximately $120 \mathrm{~m}$ during the LGM could have cut off the entry of cold CCW into the SCS through the Taiwan Strait. Hence, the northeast winter monsoon would be the main mechanism of cooling the SCS during the winter season. We further propose that changes in the $\mathrm{U}_{37}^{\mathrm{k}^{\prime \prime}}$ SST can be used to monitor the relative intensity of the winter monsoon in the northern SCS. Based on these assumptions, the paleo-winter monsoon intensity can be divided into three modes based on the SST record: (1) lower SST for the period of
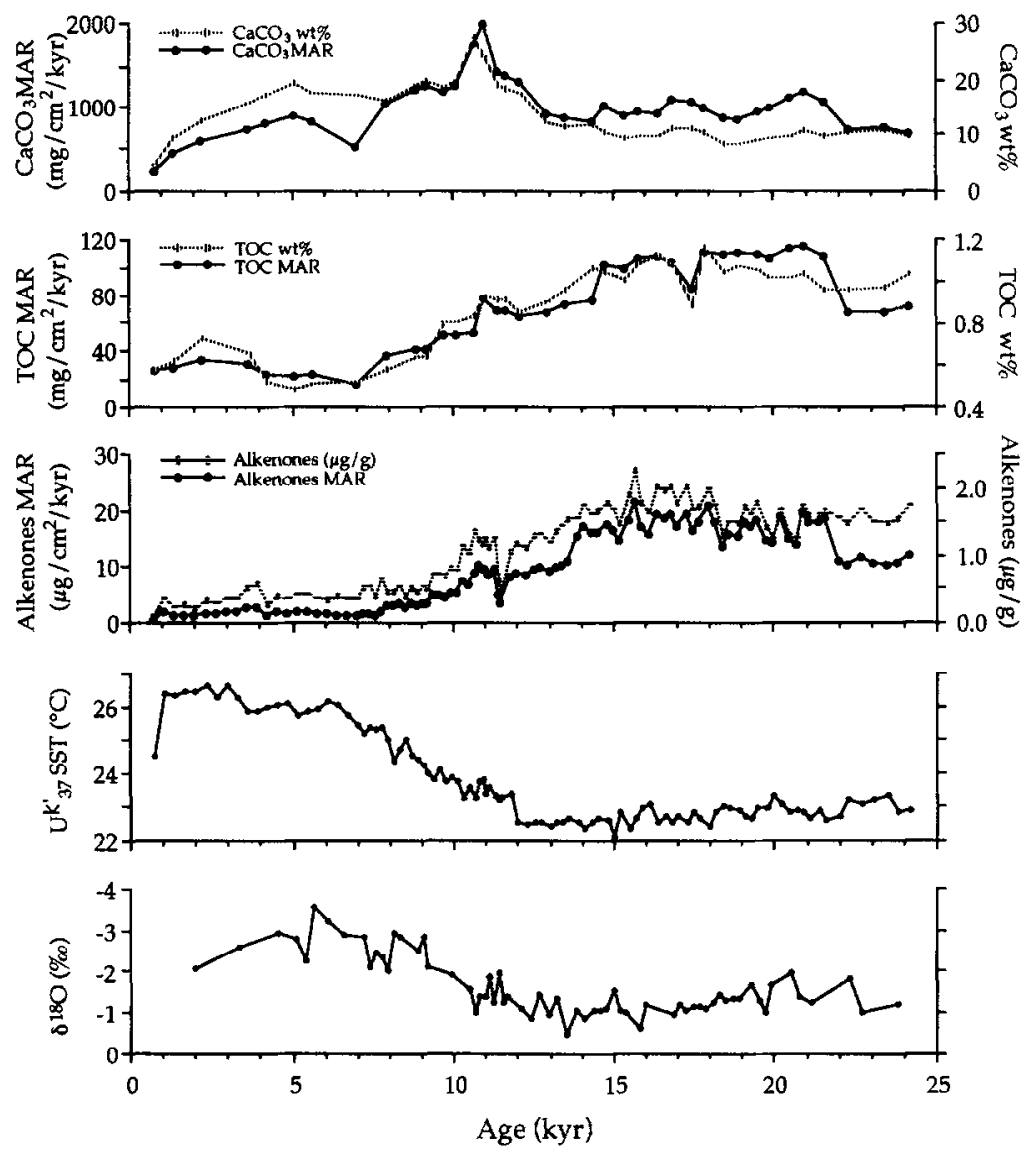

Fig. 4. Paleoceanographic proxies of the South China Sea SO50-31 KL during the last $25 \mathrm{kyr}$ : $\mathrm{CaCO}_{3}$ (wt $\%$ and $\mathrm{MAR}-\mathrm{Mass}$ Accumulation Rate), TOC (wt $\%$ and MAR), alkenones (abundance and MAR), U $\mathbf{3}^{k^{\prime}}$-derived Sea Surface Temperature (SST), and oxygen isotope composition of planktic foraminifera $G$. sacculifer. 
$25,000-12,000$ yr BP indicates a stronger winter monsoon in the last glaciation; (2) an increase in the SST from 12,000 to 6000 yг BP reflects a decrease in the winter monsoon intensity during the deglaciation and the early Holocene; and (3) higher SST since $6000 \mathrm{yr}$ BP suggests an even weaker winter monsoon in the late Holocene.

Concentration and mass accumulation rates (MARs) of TOC and alkenones have almost an inverse relationship with the SST protile (Fig. 4). They were higher during the glacial period and lower in the Holocene. The decrease started at the beginning of the deglaciation stage. The content of this biogenic component in the sediments is an end-product of their surface production and sedimentary preservation. In order to use TOC and alkenones as productivity indicators, it is imperative to demonstrate that the TOC and alkenones are primarily of marine origin and that their content variations are not determined by the preservation factor. Thunell et al. [12] and Huang et al. [10] have argued that variations in TOC in the SCS sediments mainly reflect changes in their surface productivity. The similarity of the TOC and alkenones profiles in core SO50-31 KL further demonstrates that the TOC is mainly derived from marine productivity, since alkenones are only produced by the marine algae prymnesiophytciae. Thus, the core SO50-31 KL TOC and alkenones records indicate that the productivity level was higher during the glacial period than that of the Holocene. Several processes could have contributed to this glacial increase in surface productivity, such as a local upwelling, changes in the oceanic circulation pattern to favor nutrient-trapping in the SCS, the deepening of the mixed-layer for more efficient nutrient recycling and increased nutrient supply from terrigenous sources. Based on multi-proxy analyses of a nearby core SCS90-36, Huang et al. [10] concluded that the most likely cause of the increases in glacial productivity in the SCS is the deepening of the surface layer. This conclusion is consistent with the winter monsoon history inferred from the SST record above. The increases in the winter monsoon strength would not only cause a decrease in SST, but also the deepening of the mixed layer to enhance productivity to cause the increases in the TOC and alkenone content. During the deglaciation stage, the winter monsoon began to relax, SST started to in- crease and productivity was on the decrease. During the Holocene, a weaker winter monsoon is responsible for the higher SST and lower productivity.

The carbonate content and MAR do not show a clear glacial/interglacial trend (Fig. 4). On average, glacial carbonate content is only slightly higher than that of the Holocene. The carbonate maximum is around $11 \mathrm{ka}$, coeval with the YD time. Because the core site is above the CCD but below the lysocline, carbonate dissolution plays an important role in determining the carbonate profile [14,24,38]. The peak during the $\mathrm{YD}$ time is puzzling since we did not observe significant increases in marine productivity. It probably suggests an increased preservation during the deglaciation, but further studies and more records are needed to address this question.

\subsection{Paleomonsoon record from Toushe Lake}

Previous paleoceanographic studies have already shown that the SCS summer SST has remained relatively constant over the last the last $25 \mathrm{kyr}$ $[11,14,38]$. This may seem to suggest that the summer monsoon intensity may not have changed much over this period. However, oceanic proxies such as SST are not sensitive indicators of the summer monsoon. We thus present palynological results from the Toushe lake, central Taiwan, to provide complementary records of the paleo-monsoons, especially the summer monsoon (Fig. 5).

During the last glaciation, the pollen assemblages were sequentially dominated by xerophyte Alnus (20-80\% of the tree pollen from 25,000 to $21,000 \mathrm{yr}$ $\mathrm{BP})$, herbs Gramineae (20-60\% of the total pollen from 20,500 to $16,500 \mathrm{yr}$ BP) and Cyperaceae (20$40 \%$ of the total pollen from 16,500 to $15,000 \mathrm{yr}$ BP). Other important but less dominating species were trees Salix, Ilex and Symplocos (each less than $15 \%$ of the tree pollen, not shown here) and herbs Artemisia (7-12\% of total pollen) from 25,000 to $12,000 \mathrm{yr}$ BP. Spore was almost absent in the last glaciation. Alnus is usually abundant as a pioneer plant in a newly developed forest community and also is rich on the dry/cool leeward sides of mountains of 1500-2500 m. Xerophytic Gramineae and Cypcracea without ferns commonly occur in high montane $(>2500 \mathrm{~m})$ open grass and shrubland in central Taiwan [19]. Two montane evergreen broad- 


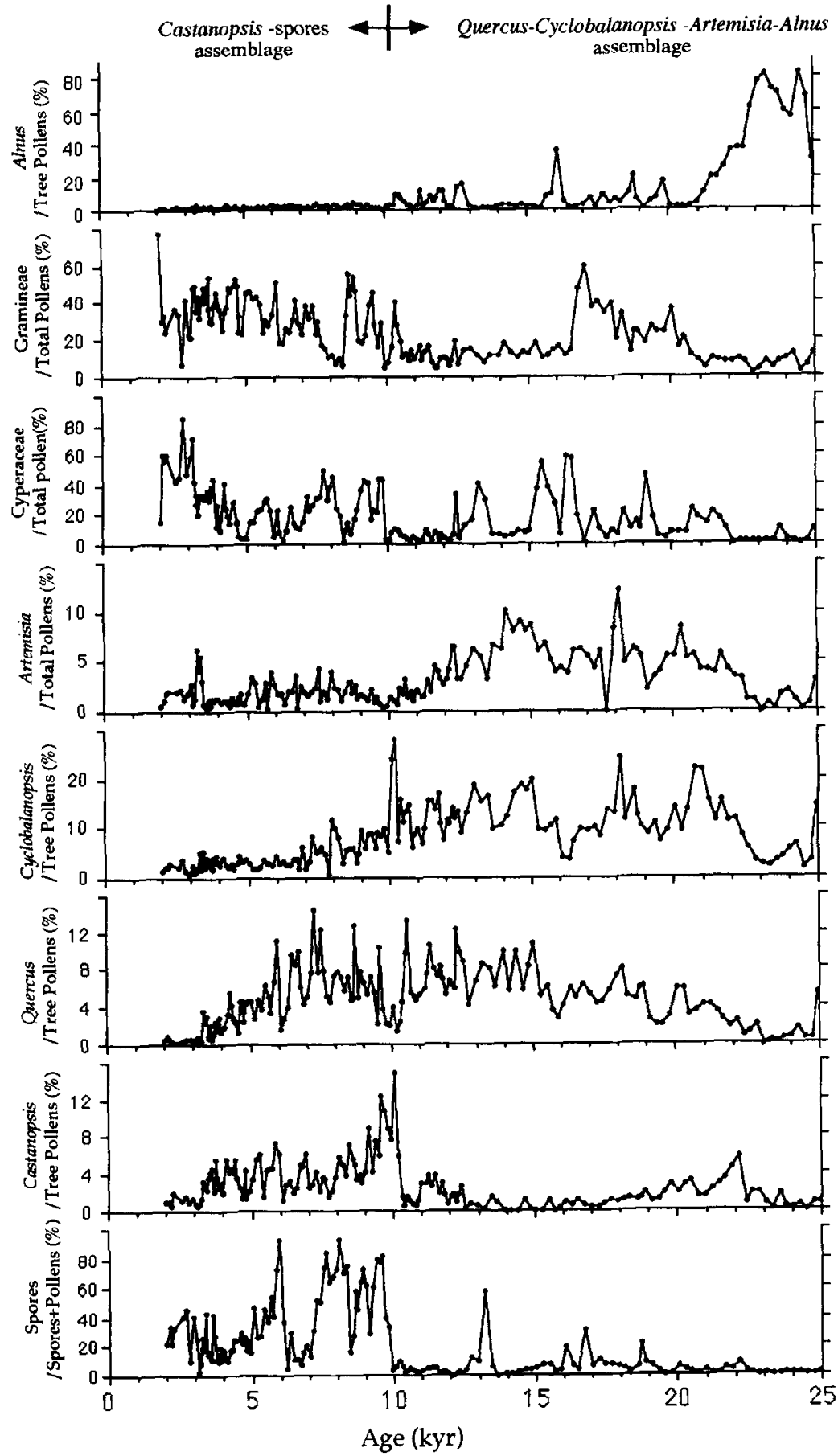

Fig. 5. Characteristic palynological composition from the Toushe Lake,central Taiwan, showing a floral change from the Quercus-Cyclo balanopsis-Artemisia-Alnus assemblage in the last glaciation to the Castanopsis-spores assemblage in the Holocene. 
leaved plants Cyclobalanopsis and Quercus were commonly observed in the last glacial interval. $\mathrm{Cy}$ clobalanopsis, the characteristic genus in the presentday Quercus Zone, was more abundant during the last glacial than in the Holocene, while the abundance of Quercus was high from 19,000 to $6000 \mathrm{yr}$ BP.

The Holocene pollen assemblage is dominated by the open herbaceous vegetation of Cyperaceae and Gramineae with ferns. The percentage of the thermophyte Castanopsis reached 14\% during the early Holocene. Castanopsis is often the main species of the submontane evergreen broad-leaved forests. In the subtropical warm and humid climate of the lowland central Taiwan $(<1500 \mathrm{~m})$, it is the dominating wooden element. The percentage of trilete and monolete spores increased sharply at the beginning of the Holocene and stayed high over the last 10,000 yr. Spores are common among warm and humid subtropical forests. Their abundance typically increases with increases in temperature and rainfall.

The palynological data show a remarkable floral change from the Quercus-CyclobalanopsisArtemisia-Alnus assemblage in the last glacial to the Castanopsis-spores assemblage in the Holocene (Fig. 5). The glacial vegetation of the Toushe lake region (elevation $650 \mathrm{~m}$ ) is analogous to the flora of the present-day Quercus Zone (elevation 1500-2500 and mean temperature range of $8-17^{\circ} \mathrm{C}$ ) of montane evergreen broad-leaved forest, or its counterpart, the Alnus Zone of deciduous forest on the leeward side, within the warm temperate to temperate climatic Zone of central Taiwan (Table 1). By contrast, the Holocene vegetation is similar to the flora of the present-day Machilus-Castanopsis vegetation Zone (elevation $500-1500 \mathrm{~m}$ and mean temperature range of $17-23^{\circ} \mathrm{C}$ ). This is the submontane evergreen broad-leaved forest of the subtropical climatic Zone in the lowland of central Taiwan. The change of pollen assemblages over the last 25,000 yr suggests that the climate of the Toushe region has changed from a cooler and drier warm temperate/temperate regime in the glacial to a warmer and more humid subtropical regime in the Holocene. We estimated that the flora were displaced by at least $850 \mathrm{~m}$ elevation during the last glacial period, implying a decreasc of $5.1^{\circ} \mathrm{C}$ in annual temperature assuming a $0.6^{\circ} \mathrm{C} / 100 \mathrm{~m}$ lapse rate [18]. The estimated tempera-

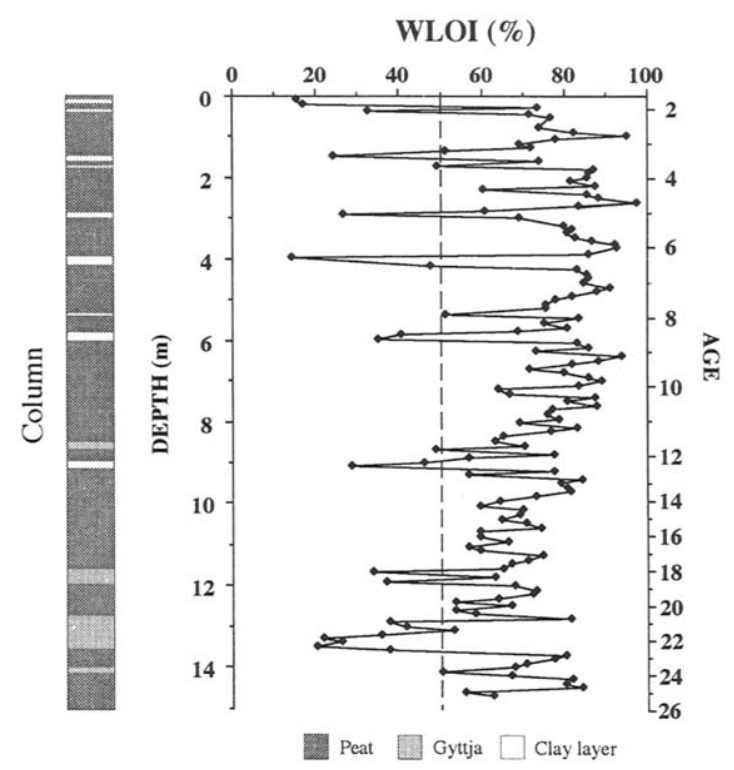

Fig. 6. Weight loss on ignition of samples from Toushe Lake, central Taiwan. The clay layers with values of weight loss on ignition $<50 \%$ were deposited by the heavy rain of the strong summer monsoon or by storms in the summer. The more frequent occurrence of these clay layers in the Holocene than that of the glacial period may have reflected a wetter summer. caused by a stronger summer monsoon.

ture decrease between the last glaciation and the Holocene in the Toushe Lake, central Taiwan, is slightly larger but comparable with that of the SCS estimated using the $\mathrm{U}_{37}^{\mathrm{k}^{\prime}}$ and foraminifera transfer function methods $[11,14]$.

The Toushe Lake core is composed of peat interbedded with thin layers of clay (each layer is about 2-4 cm thick, Fig. 6). Variations in the sedimentation rate and the occurrence frequency of the clay layers are thought to be controlled by monsoon-dominated climate changes. The sedimentation rate in the peat sequence increased from an average value of $43.4 \mathrm{~cm} / \mathrm{kyr}$ before $12,000 \mathrm{yr} \mathrm{BP}$ to $86.17 \mathrm{~cm} / \mathrm{kyr}$ (Fig. 3) in the Holocene. Diagenesis could have compacted the deeper part of the core and reduced its apparent sedimentation rate. If this is the case, we would expect a gradual change in sedimentation rate. The sharp change in sedimentation rate seems to suggest that compaction was not responsible for the sedimentation rate difference between the upper and decper parts of the core. The lower value during the last glacial period may have 
reflected low floral diversity and productivity under the dry conditions. On the other hand, the increase in lake sedimentation rate during the Holocene may indicate an increase in productivity under the warm and humid conditions, due to a strengthening of the summer monsoon after $12,000 \mathrm{yr} \mathrm{BP}$. The unusual occurrence of the clay layers interbedded in the peat sequence, as represented by low values $(<50 \%)$ in the weight loss on ignition (WLOI) curve (Fig. 6), may have resulted from the deposition of eroded clastics by heavy rains, which usually occur in the modern summer season. The frequency of the clay layers has gradually increased from 0.38 layer $/ \mathrm{kyr}$ in the last glacial to 0.5 layer $/ \mathrm{kyr}$ during the deglaciation, and to 0.75 layer/ $\mathrm{kyr}$ in the Holocene. This increase may also reflect a gradual increase in the strength of the summer monsoon or, alternatively, an increasing frequency of summer tropical storms.

To summarize the lake evidence, the Asian monsoon has experienced three modes: (1) the frequent occurrence of xerophyte and the displacement of the floral zone from 25,000 to 12,000 уг BP suggests a weak summer monsoon and a strong winter monsoon; (2) the abrupt increase in sedimentation rate and rain-related clay layers with the occurrence of the rare thermophyte from 12,000 to $10,000 \mathrm{yr} \mathrm{BP}$ indicates a shift to a weak/moderate summer monsoon during the deglaciation; and (3) a sharp increase in thermophyte combined with the high sedimentation rates since $10,000 \mathrm{yr}$ BP reveals a stronger summer monsoon since the early Holocene. However, the fluctuations in the warm and humid pollen and spores in the Holocene indicate that the interglacial mode of the climate has not been stable for the last $10,000 \mathrm{yr}$.

\section{General discussion and comparison with other records}

In our interpretation, the SCS paleoceanographic proxies reflect mainly the winter monsoon variability, while the lake palynological data record fluctuations of both summer and winter monsoons. The major conclusions regarding the monsoon history are

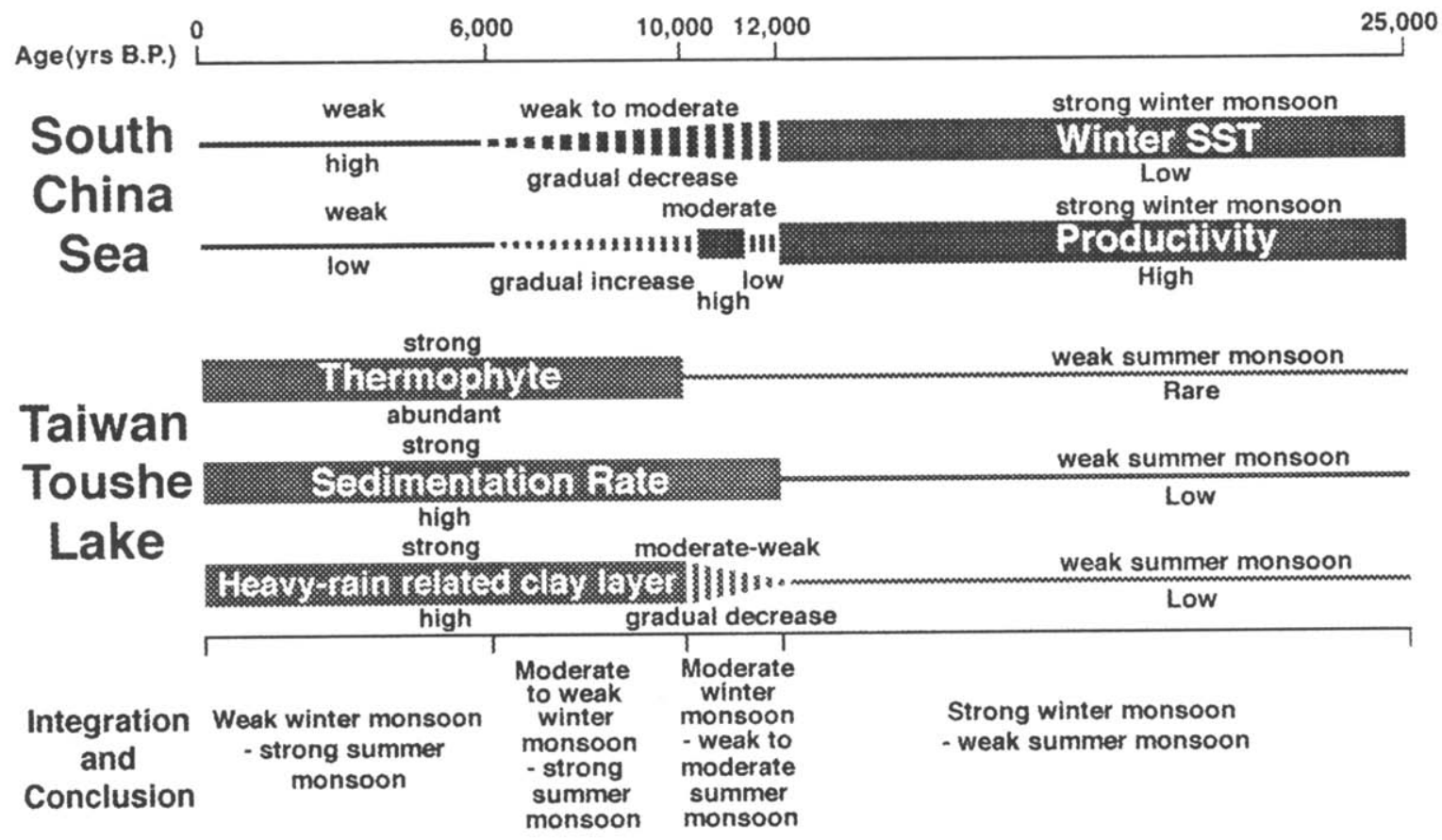

Fig. 7. An integrated monsoon history inferred from the proxy records in the South China Sea and Toushe Lake cores for the last 25,000 yr. The marine and lake records are complementary, with the marine records providing more positive evidence of the winter monsoon intensity and the lake records supporting the strong summer monsoon history. 
summarized in Fig. 7. These findings are generally in agreement with previous monsoon reconstruction and are compared briefly here.

\subsection{Comparison with previous studies from the SCS}

A few studies during the 1980 s suggested that glacial summer SST was less than $2^{\circ} \mathrm{C}$ cooler than present, and glacial winter SST was $2-4^{\circ} \mathrm{C}$ cooler than present for the SCS [39-41]. However, several recent studies have shown that the winter anomaly could have been much larger, up to $9^{\circ} \mathrm{C}[11,14,38]$. Our result seems to be in agreement with these more recent estimates. However, the mechanisms responsible for this significant winter cooling are still not resolved. Wang et al. [38] proposed that the main mechanism of this glacial cooling was the entry of the cooler subtropical western Pacific water into the SCS through the Bashi Strait. The entering cool water would also form a counterclockwise circulation pattern, which would explain the $\mathrm{N}-\mathrm{S}$ gradient in winter SST during the last glacial period. We find that the model of Wang et al. cannot explain the glacial SST and productivity results. The main difficulty with Wang et al.'s suggestion is that it requires cooler water from just outside the Bashi Strait to cool the SCS. Thunell et al. [42] and Chen et al. [43] have shown that the western tropical Pacific remained warm during the last glacial. Based on these estimates, the last glacial winter SST of the region just outside the Bashi Strait is $20-21^{\circ} \mathrm{C}$, warmer than Wang et al.'s estimates for the SCS. If this is the case, water from this region could not have cooled the SCS during the last glacial period. The model of Wang et al. also fails to explain the increase in productivity during the glacial period. In Wang's model, the entry of subtropical water would have brought nutrient-poor water into the SCS and caused a decrease in productivity. As discussed above, we propose that a stronger winter monsoon was responsible for the decrease in the glacial winter SST and the increases in surface productivity. Our monsoon model would also be in agreement with the N-S gradient of the winter SST in the glacial winter.

\subsection{Comparison with Chinese loess records}

Multiple paleomonsoon proxies, such as magnetic susceptibility, particle flux and grain size, recorded in the Chinese paleosol $\left(S_{0}\right.$, the Holocene $)$ and loess $\left(\mathrm{L}_{1}\right.$, the last glacial period) suggested a weak winter monsoon/strong summer monsoon during the Holocene and a strong winter monsoon/weak summer monsoon during the last glacial period $[4,9,44]$. Thus, our conclusions regarding the monsoon history from the tropical region are in agreement with those from the Asian continent. However, the amplitude of the monsoon influence is different in different regions. For example, the last glacial temperature was $7^{\circ} \mathrm{C}$ lower in Shaanxi [45] compared with our estimates of $4^{\circ} \mathrm{C}$ in the SCS and $5^{\circ} \mathrm{C}$ in central Taiwan. On the other hand, we estimate that last glacial rainfall was $800 \mathrm{~mm}$ lower in central Taiwan compared with $120-200 \mathrm{~mm}$ in Northern China $[45,46]$. These observations seem to indicate that the temperature effect of the winter monsoon was greater on the Asian continent, while the precipitation effect of the summer monsoon was more significant in the tropical region.

\subsection{Comparison with Indian Ocean results}

Although the Arabian SST record for the last 25 $\mathrm{ka}$ also shows a glacial/interglacial profile similar to ours $[47,48]$, direct comparison of these two records is misleading. For the Holocene, the coastal Arabian Sea SST is mainly controlled by the intensity of upwelling, which is driven by the summer southwest monsoon. Coastal upwelling also enhanced productivity, as is apparent from the much higher TOC content in the sediments (up to 6\%). On the other hand, there is not a significant upwelling system in the SCS and the SST is controlled by the surface currents which, in urn, are controlled by the oscillating winter and summer monsoon systems. For the Holocene, SCS summer SST is higher than that of the Arabian Sea while the winter SST is much lower. The SCS TOC content is also much lower, due to the lack of upwelling. During the last glacial period, Arabian Sea upwelling was reduced substantially and the main mechanism to account for the lower SST was proposed to be the increased winter monsoon strength or length [48]. In the SCS, SST was still controlled by the monsoon systems, only the winter monsoon was increased, which cooled the SST by $4^{\circ} \mathrm{C}$ during the glacial period. Thus, the Arabian Sea operated very much like the SCS during last glacial period. However, the TOC content for the two seas 
shows very different glacial/interglacial profiles. Since the surface productivity in the Arabian Sea is controlled by the coastal upwelling, the glacial reduction in upwelling strength resulted in lower productivity and lower TOC content in the sediments. However, SCS glacial TOC increased by a factor of 3 , due to the increased depth of the surface mixed layer, as a result of the increase in the winter monsoon. It appears that the records from the SCS and the Arabian Sea are consistent in indicating a stronger winter monsoon regime over a large region of the Asian continent and adjacent seas.

These comparisons confirm that the global climatic boundary conditions are probably the driving forces of the East Asian monsoon variations. Reduction in solar insolation and the depression in the Asian continental snowline during the glacial could have increased the winter atmospheric pressure gradient, thus strengthening the winter monsoon, but decreased the summer atmospheric pressure gradient to weaken the summer monsoon. More analyses and comparison of monsoon records over a longer time scale and with a larger areal coverage are needed to distinguish these forcing mechanisms and to correlate with other monsoon systems.

\section{Conclusion}

Based on the comparison of paleoclimatic records from a SCS (South China Sea) deep-sea core and a Taiwan lake peat sequence, we conclude that the Asian monsoons have varied significantly during the last $25,000 \mathrm{kyr}$. These records can be divided into three periods characterized by a strong winter monsoon/weak summer monsoon regime in the last glaciation from 25,000 to $12,000 \mathrm{yr} \mathrm{BP}$, a moderate winter monsoon/weak to moderate summer monsoon regime during the deglaciation from 12,000 to 10,000 yr BP and a moderate to weak winter monsoon/strong summer monsoon regime in the Holocene. A strong glacial winter monsoon resulted in lower winter SST, and increasing seasonality and biological productivity in the SCS. On land the enhanced winter monsoon caused a reduction in floral productivity and the sedimentation rate of peat, reduced deposition of storm-related clay layers but increased abundance of xerophyte in Toushe Lake.
The strengthening of the summer monsoon during the Holocene resulted in higher SST, lower seasonality and biological productivity in the SCS. In the lake, the increases in temperature and precipitation resulted in the increase in floral productivity and the sedimentation rate of peat, as well as the deposition of storm-related clay layers. The occurrence of thermophyte also increased.

\section{Acknowledgements}

We thank Pinxian Wang, Zhisheng An, Kuo-Yen Wei, Xihao Wu and Stephen C. Porter, P.B. Yuan and K.B. Liu for constructive discussions. [MK]

\section{References}

[1] W.L. Prell and J.E. Kutzbach, Monsoon variability over the past 150,000 years, J. Geophys. Res. 92, 8411-8425, 1987.

[2] Z. An, X. Wu, P. Wang, S. Wang, G. Dong, X. Sun, D. Zhang, Y. Lu, S. Zheng and S. Zhao, Paleomonsoons of China over the last 130,000 years, Sci. China 34, 1016-1024, 1991.

[3] S.C. Clemens and W.L. Prell, Late Pleistocene variability of Arabian Sea summer monsoon winds and continental aridity: Eolian records from the lithogenic component of deep-sea sediments, Paleoceanography 5, 109-145, 1990.

[4] Z. An, T. Liu, Y. Lu, S.C. Porter, G. Kukla, X. Wu and Y. Jua, The long-term palcomonsoon variation recorded by the loess-paleosol sequence in central China, Quat. Int. 7/8, 91-95, 1990.

[5] M.M. Yoshino, Water balance problems in monsoon Asia from the viewpoint of climatology, in: Water Balance of Monsoon Asia, M.M. Yoshino, ed., pp. 1-23, Univ. Hawaii Press, Honolulu, HI, 1971.

[6] F. Sirocko, M. Samthein, H. Erlenkeuser, H. Lange, M. Amold and J.C. Duplessy, Century-scale events in monsoonal climate over the past 24,000 years, Nature 364 , 322-324, 1993.

[7] F. Sirocko, D. Garbe-Schonberg, A. McIntyre and B. Molfino, Teleconnections between the subtropical monsoons and high-latitude climates during the last deglaciation, Science 272, 526-529, 1996.

[8] Z. An, G. Kukla, S.C. Porter and J. Xiao, Magnetic susceptibility evidence of monsoon variation on the Iness plateau of central China during the last 130,000 years, Quat. Res. 36, 29-36, 1991.

[9] B.A. Maher, R. Thompson and L.P. Zhou, Spatial and temporal reconstructions of changes in the Asian paleomonsoon: A new mineral magnetic approach, Earth Planet. Sci. Lett. $125,461-471,1994$. 
[10] C.Y. Huang, S.F. Wu, M. Zhao, M.T. Chen, C.H. Wang, X $\mathrm{Tu}$ and P.B. Yuan, Surface ocean and monsoon climate variability in the South China Sea since last glaciation, Mar. Micropaleontol., in press.

[11] L. Wang and P. Wang, Late Quaternary paleoceanography of the South China Sea: Glacial-interglacial contrasts in an enclosed basin. Paleoceanography 5, 77-90, 1990.

[12] R.C. Thunell, Q. Miao, S.E. Calvert and T.F. Pederson. Glacial-Holocene biogenic sedimentation patterns in the South China Sea: Productivity variations and surface water $\mathrm{pCO}_{2}$, Paleoceanography $7,143-162,1992$.

[13] P. Wang, Z. Jian and Z. Liu, Late Quaternary sedimentation rate in the South China Sea, in: Contributions to late Quaternary paleoceanography of the South China Sea, Z. Ye and P. Wang, eds., pp. 22-41, Qingdao Ocean Press, Qingdao, 1992 (in Chinese with English abstract).

[14] Q. Miao, R.C. Thunell and D.M. Anderson, Glacial-Holocene carbonate dissolution and sea surface temperatures in the South China and Sulu seas. Paleoceanography 9. 269$290,1994$.

[15] K. Wyrtki, Physical oceanography of the southeast Asia waters. Scientific results of maritime investigations of the South China Sea and the Gulf of Thailand 1959-1961, Naga Rep. 2, Scripps Inst. Oceanogr., La Jolla, CA, 1960.

[16] S. Chen, T. Chen, X. Xu, Z. Chen and S. Sui, The Vast South China Sea, 218 pp., China Sci. Press, Beijing, 1985 (in Chinese).

[17] S. Hellerman and M. Rosenstein, Normal monthly wind stress over the world ocean with error estimates, J. Phys. Oceanogr. 13, 1093-1104, 1983.

[18] C.H. Chi. The montane climate of Taiwan, Quat. J. Taiwan Bank 20, 155-207, 1969.

[19] H.J. Su, Studies on the climate and vegetation types of the natural forests in Taiwan (II). Altitudinal vegetation zones in relation to temperature gradient. Quart. J. Chin. For. 17. 57-73, 1984.

[20] M. Tsukada. Vegetation in subtropical Formosa during the Pleistocene glaciations and the Holocene, Paleogeogr. Paleoclimatol. Paleoecol. 3, 49-64, 1967.

[21] P.M. Liew and S.Y. Huang, Pleistocene cool stages and geological changes of western Taiwan based on palynological study. Acta Geol. Taiwan, 29, 21-32, 1991 .

[22] P.M. Liew and S.Y. Huang. A 5000 year pollen record from Chitsai Lake, central Taiwan, Terr. Atmos. Oceanic Sci. (TAO) 5, 421-429, 1994.

[23] C. Biq, The Yushan-Hsuehshan megashear zone in Taiwan, Proc. Geol. Soc. China 32. 7-20, 1989.

[24] M.L. Rottman, Dissolution of planktonic foraminifera and pteropods in the South China Sea sediments, J. Foram. Res. 9. 41-49. 1979

[25] S.C. Brassell, G. Eglinton, I.T. Marlowe, U. Pflaumann and M. Sarnthein, Molecular stratigraphy: A new tool for climatic assessment, Nature 320, 129-133, 1986.

[26] F.G. Prahl and S.G. Wakeham, Calibration of unsaturation patterns in long-chain ketone composition for palaeotemperature assessment, Nature 330, 367-369, 1987.

[27] M. Zhao. N.A.S. Beveridge, N.J. Shackleton, M. Sarnthein and G. Eglinton, Molecular stratigraphy of cores off northwest Africa: Sea surface temperature history over the last 80 ka, Paleoceanography 10,661-675, 1995.

[28] F.G. Prahl, L.A. Muehlhausen and D.L. Zahnle, Further evaluation of long-chain alkenones as indicators of paleoceanographic conditions, Geochim. Cosmochim. Acta 52, 2303-2310, 1988.

[29] M. Sarnthein. K. Winn, J.C. Duplessy and M.R. Fontugne, Global variations of surface ocean productivity in low and mid latitudes: influence on $\mathrm{CO}_{2}$ reservoirs of the deep ocean and atmosphere during the last 21,000 years, Paleoceanography 3, 361-399, 1988.

[30] I.T. Marlowe. S.C. Brassell, G. Eglinton and J.C. Green, Long chrain unsaturated ketones and esters in living algae and marine sediments, Org. Geochem. 16, 135-141, 1984.

[31] F.G. Prahl, N. Pisias, M.A. Sparrow and A. Sabin, Assessment of sea-surface temperature at $42^{\circ} \mathrm{N}$ in the California Current over the last 30,000 years, Paleoceanography 10 . 763-773. 1995.

[32] E. Sikes and L.D. Keigwin. Equatorial Atlantic sea surface temperature for the last $30 \mathrm{kys}$ : A comparison of $\mathrm{U}_{37}^{\mathrm{k}^{\prime}}, \delta^{18} \mathrm{O}$ and foraminiferal assemblage temperature estimates, Paleoceanography 9, 31 45, 1994.

[33] M.H. Conte, G. Eglinton and L,A.S. Madureira, Long-chain alkenones and alkyl alkenoates as palaeotemperature indicators: their production, flux and early sedimentary diagenesis in the Eastern North Atlantic. Org. Geochem. 19. 287-298. 1992.

[34] M.R. Chapman, N.J. Shackleton, M. Zhao and G. Eglinton, Faunal and alkenone reconstructions of subtropical North Atlantic surface hydrography and paleotemperature over the past 28 k.y., Paleoceanography 1I, 343-358, 1996.

[35] E.L. Sikes, J.W. Farrington and L.D. Keigwin, Use of the alkenone unsaturation ratio $U_{37}^{k^{\prime}}$ to determine past sea surface temperatures: Core-top SST calibrations and methodology considerations, Earth Planet. Sci. Lett. 104, 36-47. 1991.

[36] A. Rosell-Melé, G. Eglinton, U. Pflaumann and M. Sarnthein. Atlantic core-top calibration of the $U_{17}^{k}$ index as sea-surface palaeotemperature indicator, Geochim. Cosmochim. Acta 59, 3099-3107. 1995.

[37] State Oceanic Administration, A report of comprehensive investigation on environmental resources in the central part of the South China Sea. pp. 149-162. China Ocean Press, 1988 (in Chinese).

[38] P. Wang, L. Wang, Y. Bian and Z. Jian, Late Quaternary Paleoceanography of the South China Sea: surface circula tion and carbonate cycles, Mar. Geol. 127, 145-165, 1995.

[39] CLIMAP (Long-Range Investigation, Mapping and Prediction Members), Seasonal reconstruction of the Earth's surface at the last glacial maximum. GSA Map Chart Ser. MC-36, 1-18, 1981

[40] T.C. Moore, L.H. Burckle, K. Geitzenaauer, B. Lus, A. Molina-Cruz, J.H. Robertson, H. Sacks, C. Sancetta, J. Thiede, P. Thompson and $\mathrm{C}$. Wenkam. The reconstruction of sea surface temperature in the Pacific Ocean of 18,000 B.P.. Mar. Micropaleontol. 5, 215-247, 1980.

[41] R.P. Thompson, Planktonic foraminifera in the western North 
Pacific during the past 150,000 years: Comparison of modern and fossil assemblages, Palaeogeogr. Palaeoclimatol. Palaeoecol. 35, 241-279, 1981.

[42] R. Thunell, D. Anderson, D. Gellar and Q. Miao, Sea-surface temperature for the tropical Western Pacific during the last glaciation and their implications for the Pacific warm pool, Quat. Res. 41, 255-264, 1994.

[43] M.P. Chen, C.K. Huang, L. Lo and C.H. Wang, Late Pleistocene paleoceanography of the Kuroshio Current in the area offshore Southeast Taiwan, Terr. Atmos. Oceanic Sci. (TAO) 3, 81-110, 1992.

[44] J. Xiao, S.C. Porter, Z. An, K. Xiao and S. Yoshikawa, Grain size of quartz as an indicator of winter monsoon strength on the loess plateau of central China during the last $130,000 \mathrm{yr}$, Quat. Res. 43, 22-29, 1995.

[45] N. Wu, H. Lu, X. Sun, Z. Guo, J. Liu and J. Han, Climate factor transfer function from opal phytolith and its application in paleoclimate reconstruction of China Loess-Paleosol sequence, Sci. Geol. Sin. Suppl. Issue 1. 105-114, 1995.
[46] M.H. Winkler and P.K. Wang, The late-Quaternary vegetation and climate of China, in: Global Climates Since the Last Glacial Maximum, H.E. Wright Jr., J.E. Kutzbach, T. Webb III, W.F. Ruddiman, F.A. Street-Perrott and P.J. Bartlein, eds., pp. 221-261, Univ. Minnesota Press, Minneapolis, MN, 1993.

[47] F. Rostek, G. Ruland, F.C. Bassinot, P.J. Muller, L.D. Labeyrie, Y. Lancelot and E. Bard, Reconstructing sea surface temperature and salinity using $\delta^{18} \mathrm{O}$ and alkenone records, Nature 364, 319-321, 1993.

[48] K.-C. Emeis, D.M. Anderson. H. Doose, D. Kroon and D. Schulz-Bull, Sea-surface temperature and the history of monsoon upwelling in the Northwest Arabian Sea during the last 500,000 years, Quat. Res. 43, 355-361, 1995.

[49] National Oceanic and Atmospheric Administration (NOAA), World Ocean Atlas, Natl. Oceanogr. Data Center, Ocean Climate Lab., Washington, DC, 1994. 